\title{
Cardioprotective Effect of Low Level of LDL Cholesterol on Perioperative Myocardial Injury in Off-Pump Coronary Artery Bypass Grafting
}

\author{
Tomasz Kamil Urbanowicz ${ }^{1, *(1)}$, Anna Olasińska-Wiśniewska ${ }^{1}{ }^{(}$, Michał Michalak $^{2}{ }^{\circledR}$, Aleksandra Gąsecka ${ }^{3}$, \\ Michał Rodzki ${ }^{1}$, Bartłomiej Perek ${ }^{1} \mathbb{D}$ and Marek Jemielity ${ }^{1}$ \\ 1 Cardiac Surgery and Transplantology Department, Poznan University of Medical Sciences, \\ 61-848 Poznań, Poland; annaolasinska@ump.edu.pl (A.O.-W.); michal.rodzki@skpp.edu.pl (M.R.); \\ bperek@ump.edu.pl (B.P.); mjemielity@poczta.onet.pl (M.J.) \\ 2 Department of Computer Science and Statistics, Poznan University of Medical Sciences, \\ 60-529 Poznań, Poland; michal@ump.edu.pl \\ 3 1st Chair and Department of Cardiology, Medical University of Warsaw, 02-106 Warsaw, Poland; \\ gaseckaa@gmail.com \\ * Correspondence: tomasz.urbanowicz@skpp.edu.pl; Tel.: +48-61-854-9210
}

\section{check for}

updates

Citation: Urbanowicz, T.K.; Olasińska-Wiśniewska, A.; Michalak, M.; Gąsecka, A.; Rodzki, M.; Perek, B.; Jemielity, M. Cardioprotective Effect of Low Level of LDL Cholesterol on Perioperative Myocardial Injury in Off-Pump Coronary Artery Bypass Grafting. Medicina 2021, 57, 875. https://doi.org/10.3390/ medicina57090875

Academic Editor: Tomasz Zieliński

Received: 8 August 2021

Accepted: 25 August 2021

Published: 26 August 2021

Publisher's Note: MDPI stays neutral with regard to jurisdictional claims in published maps and institutional affiliations.

Copyright: (C) 2021 by the authors Licensee MDPI, Basel, Switzerland. This article is an open access article distributed under the terms and conditions of the Creative Commons Attribution (CC BY) license (https:// creativecommons.org/licenses/by/ $4.0 /)$.

\begin{abstract}
Background and Objectives: Coronary artery disease is still a major cause of death in developed countries. Low-density lipoprotein cholesterol (LDL-C) lowering with statin therapy is a key strategy in major acute coronary events' prevention. The aim of the study was to establish if there is a cardioprotective effect of pre-operative LDL lowering therapy on perioperative myocaridal injury in patients undergoing off-pump coronary artery bypass grafting (CABG). Moreover, the impact of pre-operative LDL level on long term outcome was analysed. Materials and Methods: The retrospective single center analysis included 662 consecutive patients (431 (65\%) males and $231(35 \%)$ female, mean age of $65 \pm 8$ ) referred for cardiac surgery due to stable chronic coronary syndrome between 2012-2018. The follow up was 9 years. Results: A statistically significant difference was found in postoperative serum Troponin-I for LDL thresholds of $1.8 \mathrm{mmol} / \mathrm{L}(p=0.009), 2.6 \mathrm{mmol} / \mathrm{L}(p=0.03)$ and $3.0 \mathrm{mmol} / \mathrm{L}(p=0.001)$. The results indicate that cardioprotective role of LDL is achieved within LDL concentration rate below $1.8 \mathrm{mmol} / \mathrm{L}(<70 \mathrm{mg} / \mathrm{dL})$. Five patients died perioperatively, whereas 1-year and 9-year overall mortality rates were $4 \%(n=28)$ and $18.6 \%(n=123)$, respectively. Comparing the survival group with diseased, Mann-Whitney $U$ test showed a statistically significant difference in HDL-C $(p=0.007)$, Troponin $(p=0.009)$, Castelli index $(p=0.001)$ and atherogenic index $(p=0.004)$. Preoperative levels of total cholesterol, LDL-C and HDL-C did not significantly differ between survivors and diseased. The 9-year mortality risk did not differ significantly between subgroups divided according to LDL-C thresholds of $1.4 \mathrm{mmol} / \mathrm{L}$ ( $55 \mathrm{mg} / \mathrm{dL}), 1.8 \mathrm{mmol} / \mathrm{L}(70 \mathrm{mg} / \mathrm{dL})$, $2.6 \mathrm{mmol} / \mathrm{L}(100 \mathrm{mg} / \mathrm{dL})$ and $3.0 \mathrm{mmol} / \mathrm{L}(116 \mathrm{mg} / \mathrm{dL})$. Conclusions: Preoperative low level of LDL-C cholesterol (below $1.83 \mathrm{mmol} / \mathrm{L}, 70 \mathrm{mg} / \mathrm{dL}$ ) has a cardioprotective effect on perioperative myocardial injury in off-pump coronary artery bypass grafting.
\end{abstract}

Keywords: cardiac surgery; cardiovascular disease; prognosis; therapy; drugs

\section{Introduction}

Coronary artery disease is still a major cause of death in developed countries. Genetic and environmental factors combined with lifestyle pose a risk for the development of atherosclerotic disease. Complex coronary disease can be treated with optimal medical therapy and percutaneous or surgical revascularization. The off-pump surgery is a safe option due to its relatively low complications rate [1,2]

Low-density lipoprotein cholesterol (LDL-C) lowering with statin therapy is a key strategy in acute and chronic coronary syndromes' prevention according to randomized 
clinical studies and high-volume meta-analyses [3-5]. Problems with patients' noncompliance may be overcome with good meticulous argumentation supported by scientific evidence [6]. Therefore, studies which prove the cardioprotective role of LDL lowering are crucial [7].

The protective effect of pretreatment statin therapy on periprocedural myocardial damage was presented in several large trials [8-10]. The surgical intervention may be related to some defined complications, including the amount of myocardial injury [11]. Preoperative statin therapy is suspected to improve post-operative results, but in several studies it did not influence the risk of either perioperative acute kidney dysfunction or long-term graft patency [12,13].

The aim of the study was to establish if there is a cardioprotective effect of preoperative LDL lowering therapy on perioperative myocardial injury in patients undergoing off-pump coronary artery bypass grafting (CABG). Moreover, the impact of pre-operative LDL level on long term outcome was analysed.

\section{Materials and Methods}

The study was based on retrospective analysis of 662 consecutive patients including $431(65 \%)$ males and $231(35 \%)$ females of mean age of $65 \pm 8$ referred for cardiac surgery to our department due to stable chronic coronary syndrome between 2012-2018. Patients qualified for cardiac surgery based on coronary angiography results, with $417(63 \%)$ and $245(37 \%)$ presenting three vessel and left main (LM) disease. The concomitant diseases included: arterial hypertension in 477 (72\%), diabetes mellitus in $218(33 \%)$, chronic obstructive pulmonary disease $120(18 \%)$ and peripheral artery disease in $93(14 \%)$ patients. All patients were treated with lipid lowering agents including simvastatin $(n=203)$, atorvastatin $(n=236)$, and rosuvastatin $(n=223)$. Demographical and clinical data are outlined in Table 1.

Table 1. Demographical and clinical data.

\begin{tabular}{|c|c|}
\hline Parameter & No-662 \\
\hline Age (year) (mean, SD) & $65 \pm 8$ \\
\hline Gender (male/female) $(n, \%)$ & $431(65 \%) / 231(35 \%)$ \\
\hline \multicolumn{2}{|l|}{ Indication for surgery: } \\
\hline $\begin{array}{ll}- & \text { Left main stenosis }(n, \%) \\
- & 3 \text { vessels disease }(n, \%)\end{array}$ & $\begin{array}{l}245(37 \%) \\
417(63 \%)\end{array}$ \\
\hline \multicolumn{2}{|l|}{ Concomitant diseases: } \\
\hline $\begin{array}{ll}- & \text { Arterial hypertension }(n, \%) \\
- & \text { Diabetes mellitus }(n, \%) \\
- & \text { COPD }(n, \%) \\
- & \text { Peripheral artery disease }(n, \%) \\
\end{array}$ & $\begin{array}{r}477(72 \%) \\
218(33 \%) \\
120(18 \%) \\
93(14 \%) \\
\end{array}$ \\
\hline \multicolumn{2}{|l|}{ Preoperative labolatory parameters: } \\
\hline $\begin{array}{ll}\text { - } & \text { Cholesterol }(\mathrm{mmol} / \mathrm{L})((\text { median, Q1-Q3) } \\
\text { - } & \text { HDL-C (mmol/L) (median, Q1-Q3) } \\
\text { - } & \text { LDL-C (mmol/L) (median, Q1-Q3) } \\
\text { - } & \text { Rastelli index (median, Q1-Q3) } \\
\text { - } & \text { Atherogenic index (median, Q1-Q3) }\end{array}$ & $\begin{array}{c}4.0(3.42-4.77) \\
1.27(1.06-1.5) \\
2.1(1.6-2.7) \\
3.18(2.6-3.9) \\
1.7(1.2-2.2) \\
\end{array}$ \\
\hline \multicolumn{2}{|l|}{ Postoperative myocardial injury parameters: } \\
\hline $\begin{array}{ll}- & \max \text { Troponin I }(\mathrm{ng} / \mathrm{mL})(\text { median, Q1-Q3) } \\
\text { - } & \max \text { Ck-MB }(\mathrm{ng} / \mathrm{mL})(\text { median, Q1-Q3) }\end{array}$ & $\begin{array}{r}2.43(0.95-5.96) \\
7.6(2.93-14.4)\end{array}$ \\
\hline Observation time (years) (mean, SD) & $5.5 \pm 2.6$ \\
\hline
\end{tabular}

Abbreviations: COPD—chronic obstructive pulmonary disease, HDL-C-high-density lipoprotein cholesterol, LDL-C—low-density lipoprotein cholesterol, max - maximum, Q-quartile. 
All the procedures were performed via complete median sternotomy without cardiopulmonary bypass as an off-pump coronary artery bypass grafting (OPCAB) technique.

On the day of admission, blood samples including serum lipid profile analysis were collected. The Castelli indices 1 (total serum cholesterol/HDL-C) and 2 (LDL-C/HDL-C) were calculated [14]. During the postoperative time, the serum troponin-I (Trop-I) levels and kinase creatinine isoenzyme (CK-MB) were collected. The preoperative LDL-C levels were compared with myocardial injury markers including Troponin-I serum levels. We subdivided the presented group into subgroups representing the following thresholds of LDL-C according to ECS guidelines: below $1.43 \mathrm{mmol} / \mathrm{L}$ ( $55 \mathrm{mg} / \mathrm{dL}$ ), below $1.83 \mathrm{mmol} / \mathrm{L}$ (70 mg/dL), below $2.59 \mathrm{mmol} / \mathrm{L}$ (100 mg/dL) and below $3.0 \mathrm{mmol} / \mathrm{L}$ (116 mg/dL) [15].

The median follow up was $5.5 \pm 2.6$ years and up to 9 years (2012-2021) and included analysis of all-cause mortality confirmed by the Polish National Health Service database.

All patients signed written informed consent for routine surgery. The study received positive agreement from the Poznan University of Medical Sciences' Ethics Committee (No 55/20 from 16 January 2020).

\section{Statistical Analysis}

Continuous variables were reported as mean \pm standard deviation (SD) if data followed the normal distribution (Shapiro-Wilk test), otherwise the data were presented as median and interquartile range $\left(Q_{1}-Q_{3}\right)$. Categorical data were presented as numbers and percentages. The comparison of interval parameters between survivors and deceased group was performed by Mann-Whitney. The max troponin I level between groups denoted according to ECS cardiovascular LDL-C threshold was analyzed by Kruskal-Wallis and Dunn's post-hoc test. Categorical data were analyzed by chi-square test for independence. The Cox's proportional hazard regression model was used to check if analyzed demographical and clinical data could be a risk factor for all-cause death. The analysis was performed with the use of statistical package TIBCO Software Inc., Palo Alto, CA, USA (2017). Statistica (data analysis software system), version 13. http://statistica.io (Since 2000, site license). All tests were considered significant at $p<0.05$.

\section{Results}

All patients admitted for surgical procedure were on statin therapy. The precise data is presented above Table 1 . The mean values of preoperative serum cholesterol, LDL-C, high-density lipoprotein cholesterol (HDL-C) levels are presented in Table 1. All patients underwent off-pump coronary artery bypass grafting with mean skin-to-skin time of $142 \pm 41 \mathrm{~min}$ and mean hospitalization time was $11 \pm 4$ days.

\subsection{Myocardial Injury}

We compared the postoperative myocardial injury markers between LDL-C subgroups. Mann-Whitney test did not reveal significant statistical difference between max postoperative Troponin-I and subgroup of patients with LDL-C results below $1.4 \mathrm{mmol} / \mathrm{L}(p=0.08)$. There was a statistically significant difference noticed in postoperative serum Troponin-I for LDL-C thresholds of $1.8 \mathrm{mmol} / \mathrm{L}(p=0.009), 2.6 \mathrm{mmol} / \mathrm{L}(p=0.03)$ and $3.0 \mathrm{mmol} / \mathrm{L}$ $(p=0.001)$. The multiple comparison $p$ values comparing postoperative Troponin-I and LDL-C values are presented in Table 2 . The results indicate that cardioprotective role of LDL-C is achieved within LDL-C concentration rates below $1.8 \mathrm{mmol} / \mathrm{L}(<70 \mathrm{mg} / \mathrm{dL})$.

\subsection{Perioperative and Long-Term Survival}

There were five $(0.8 \%)$ perioperative deaths in the presented group and $4 \%(n=28)$ overall 1-year mortality. There were $13(2 \%)$ postoperative excessive bleedings requiring reoperation. In the 9-year follow-up overall mortality rate was $18.6 \%(n=123)$.

Comparing the survival group with diseased, Mann-Whitney $\mathrm{U}$ test found statistically significant difference in HDL-C $(p=0.007)$, Troponin $(p=0.009)$, Castelli index $(p=0.001)$ and atherogenic index $(p=0.004)$. Preoperative levels of total cholesterol, LDL-C and 
HDL-C did not significantly differ between survivors and diseased. Despite significant difference between both groups, the Cox regression analysis did not confirm any of the presented factors as a significantly predictive.

Table 2. Kruskal-Wallis and Dunn's post-hoc test results for max Troponin-I serum level vs LDL-C.

\begin{tabular}{ccccc}
\hline & \multicolumn{4}{c}{ Kruskal-Wallis Test: H $(\mathbf{4}, n=640)=\mathbf{1 3 . 1 4 9} p=\mathbf{0 . 0 1 0 6}$} \\
\cline { 2 - 5 } & LDL-C below1.43 & LDL-C 1.43-1.82 & LDL-C 1.82-2.59 & LDL-C 2.59-3.0 \\
\hline LDL-C below1.4 mmol/L & & & \\
LDL-C 1.4-1.8 mmol/L & 1.0000 & 1.0000 & 1.0000 \\
LDL-C 1.8-2.6 mmol/L & 1.0000 & 1.0000 & 0.3961 & 0.2168 \\
LDL-C 2.6-3.0 mmol/L & 1.0000 & 0.0294 & \\
LDL-C above 3.0 mmol/L & 0.0166 & & & \\
\hline
\end{tabular}

Abbreviations: LDL-C-low-density lipoprotein cholesterol.

We subdivided the study group into subgroups representing the following thresholds of LDL-C according to ECS guidelines: below $1.4 \mathrm{mmol} / \mathrm{L}$ ( $55 \mathrm{mg} / \mathrm{dL}$ ), below $1.8 \mathrm{mmol} / \mathrm{L}$ (70 mg/dL), below $2.6 \mathrm{mmol} / \mathrm{L}(100 \mathrm{mg} / \mathrm{dL})$ and below $3.0 \mathrm{mmol} / \mathrm{L}(116 \mathrm{mg} / \mathrm{dL})$ and analyzed the 9-year mortality rates (Figure 1).

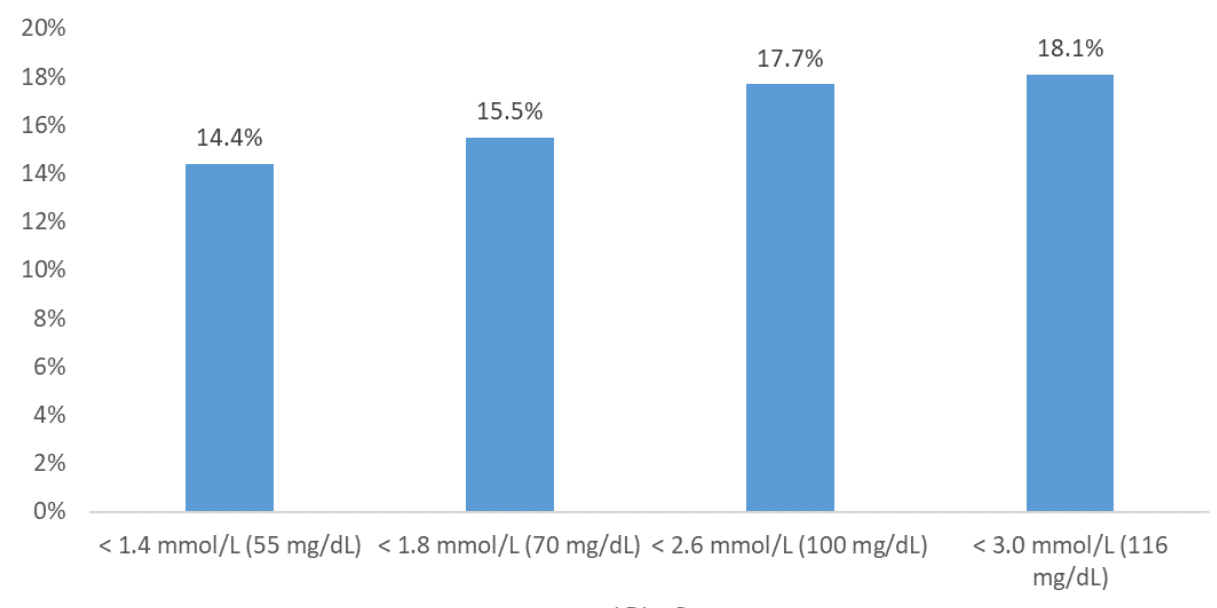

LDL - C

Figure 1. Nine-year cumulative mortality in subgroups divided according to ECS cardiovascular LDL-C threshold.

First, we evaluated patients below and above the threshold of $1.4 \mathrm{mmol} / \mathrm{L}$, and then $1.8 \mathrm{mmol} / \mathrm{L}$. Finally, we compared mortality rates in subgroups divided according to LDL-C ranges (Table 3 ).

Table 3. Nine-year mortality in subgroups divided according to ECS cardiovascular LDL-C threshold.

\begin{tabular}{ccc}
\hline LDL-C Level & $\begin{array}{c}\text { Mortality in the Subgroups } \\
\boldsymbol{n} \mathbf{( \% )}\end{array}$ & $\begin{array}{c}\text { Total Number of Patients in the } \\
\text { Subgroup }\end{array}$ \\
\hline below $1.4 \mathrm{mmol} / \mathrm{L}$ & $19(14.8 \%)$ & 128 \\
$1.4-1.8 \mathrm{mmol} / \mathrm{L}$ & $17(16.2 \%)$ & 105 \\
$1.8-2.6 \mathrm{mmol} / \mathrm{L}$ & $43(20.2 \%)$ & 213 \\
$2.6-3.0 \mathrm{mmol} / \mathrm{L}$ & $16(20.5 \%)$ & 78 \\
above $3.0 \mathrm{mmol} / \mathrm{L}$ & $28(23.3 \%)$ & 120 \\
\hline
\end{tabular}

Chi-square $p$-value $=0.4435$ 
There were $128(20 \%)$ and $516(80 \%)$ patients with LDL-C below and above $1.4 \mathrm{mmol} / \mathrm{L}$. The mortality in the presented subgroup was $19(14.8 \%)$ vs $104(20.2 \%)$, respectively. The difference was not statistically significant. The number of patients presenting values below the threshold of $1.8 \mathrm{mmol} / \mathrm{L}$ was $233(36 \%)$, and 411 above $(64 \%)$. The mortality risk in presented subgroup was $15.5 \%(n=36)$ vs $21.2 \%(n=87)$, respectively. The difference was not statistically significant.

The study group was divided into subgroups representing the following thresholds of LDL-C according to ECS guidelines [15]: $1.4 \mathrm{mmol} / \mathrm{L}$ (55 mg/dL), $1.8 \mathrm{mmol} / \mathrm{L}$ (70 mg/dL), $2.6 \mathrm{mmol} / \mathrm{L}(100 \mathrm{mg} / \mathrm{dL})$ and $3.0 \mathrm{mmol} / \mathrm{L}(116 \mathrm{mg} / \mathrm{dL})$. We compared (Table 3$)$ consecutive subgroups in terms of nine-year mortality, but these results also were not statistically significant.

\section{Discussion}

The results of our study present the LDL-C values that may have a cardioprotective role during OPCAB procedures. A significant relation between preoperative LDL-C values and postoperative Troponin-I release was observed. The LDL-C below $1.83 \mathrm{mmol} / \mathrm{L}(<70 \mathrm{mg} / \mathrm{dL})$ characterized the patients with significant reduction of postoperative Troponin-I release. Therefore, we proved that pre-operative LDL lowering is important for peri-operative management. Statin therapy may protect the heart muscle from the intra-operative and post-operative injury or at least diminish it. The protection may result from pleiotropic effect of statins, including anti-inflammatory effect and plaque stabilization. Similar results were presented in the meta-analysis of Farkouh et al. regarding percutaneous coronary interventions (PCI) [16]. Navarese et al. also pointed out the significance of intensive statin therapy on cardiovascular risk reduction [17].

Statins' role in atherosclerotic plaque stabilization and regression is already known. The EASY-FIT study presented the statin effect on fibrous cap thickness, suggesting that LDL-C $<70 \mathrm{mg} / \mathrm{dL}$ stabilizes coronary atherosclerotic plaques [18]. The use of lipidlowering medications may slow down the rate of atherosclerosis disease progression, as was shown in the ASTERIOD trial [19]. The inflammatory concept in the pathogenesis of atherosclerosis recognizes atherogenesis as an active process with mononuclear phagocytes' contribution in all stages of this disease [20]. The beneficial effects of statins relate to their anti-inflammatory properties such as reduction of T-cell activity, chemokines, cytokines, and adhesion molecules including ICAM-1, lymphocyte function-associated antigen-1, monocyte chemotactic protein-1 and Th1-type chemokine receptors on T cells' inhibition [21].

In the multicenter REVERSAL trial, Nissen et al. reported reduced progression of coronary atherosclerosis by change in percent atheroma volume achieved by statin therapy [22]. The SATURN trial proved regression of atherosclerotic plaque in patients receiving high-intensity statin therapy [23]. Interestingly, due to individual plaque anatomy and individualized systemic biological effect of statins, the optimal dosage may be difficult to determine [24]. Recently, a very aggressive LDL-C reduction was shown to decrease the risk for cardiovascular events and improve survival with a threshold as low as $40 \mathrm{mg} / \mathrm{dL}$ in the REDUCE-IT trial [25].

Cardioprotective role of statin therapy during PCI procedures is related to myocardial perfusion improvement resulting in myocardial infarction risk reduction [26]. Marenzi et al. presented the cardioprotective role of long-term statin therapy on infarct size in patients with ST elevation myocardial infarction treated with PCI in multivariable analysis [27]. Auguardo et al. proved statin influence on Troponin release after PCI as an independent myocardial protection predictor [28].

Troponin release after PCI does not straightforwardly predict all-cause mortality according to Lippi et al. [29]. Isolated myocardial injury diagnosis based only on Troponin-I release does not translate into unfavourable prognosis [30]. On the contrary, in metaanalysis performed by Nienhuis et al., nonfatal myocardial infarction and mortality risk were increased in patients with post-procedural troponin elevation [31]. In surgical revas- 
cularization, the study of Wang et al. confirmed that combination of Troponin release and electrocardiographic changes with echocardiographic ejection fraction deterioration was a mortality predictor in multivariable analysis, contrary to sole Troponin release [32]. Undoubtedly, Troponin is the most reliable myocardial injury marker [33]. In the study of Machado et al. study and the meta-analysis of Buse et al., the Troponin release predicted 30-day and mid-term mortality following coronary artery bypass grafting, respectively [34,35]. The comparison of these studies support the importance of Troponin release. This may explain the results of our study regarding lack of predictive Troponin values in the long-term, 9-year observation time.

Surprisingly, the pre-operative LDL level did not correspond with long term mortality. Navarese et al. in their publication presenting meta-analyses and meta-regressions, pointed out that more intensive LDL-C lowering compared with less intensive strategy was associated with a greater reduction in risk of total and cardiovascular mortality in trials of patients with higher baseline LDL-C levels (100 mg/dL) [17]. Therefore, it might be expected that, in our study, long term survival would be improved in patients with lower baseline LDL-C levels. However, we must point out that our study reflects a real-life registry, without a strict researchers' influence on patients' compliance, including patients with different types of statin used before and after surgery in terms of duration, type and dosage. Though this may be treated as a limitation, these observation incline towards even more strict control of statin use in patients with coronary artery disease treated with coronary artery bypass grafting, both before and after the procedure.

\section{Conclusions}

Low level of LDL cholesterol (below $1.8 \mathrm{mmol} / \mathrm{L}, 70 \mathrm{mg} / \mathrm{dL}$ ) has a cardioprotective effect on perioperative myocardial injury in off-pump coronary artery bypass grafting.

Author Contributions: Conceptualization: T.K.U., A.O.-W., A.G., B.P., M.J. Methodology: T.K.U., M.M. Software: M.M. Validation: M.M. Formal analysis: M.M. Investigation: T.K.U., A.O.-W., M.R. Resources: T.K.U., M.R. Data curation: T.K.U., A.O.-W., M.R. Writing-original draft preparation: T.K.U. Writing—review and editing: T.K.U., M.M., A.O.-W., A.G., B.P., M.J. Visualization: T.K.U. Supervision: B.P., M.J. Project administration: M.J. Funding acquisition: B.P., M.J. All authors have read and agreed to the published version of the manuscript.

Funding: This research received no external funding.

Institutional Review Board Statement: The study was conducted according to the guidelines of the Declaration of Helsinki and approved by the Ethics Committee) of Poznan University of Medical Sciences (protocol code 55/20, 16 January 2020-date of approval).

Informed Consent Statement: Informed consent was obtained from all subjects involved in the study as standard procedure.

Data Availability Statement: All data will be available under correspondence e-mail address for 3 years following the publication after request that would be justifiable.

Conflicts of Interest: The authors declare no conflict of interest.

\section{References}

1. Meharwal, Z.S.; Mishra, Y.K.; Kohli, V.; Singh, S.; Bapna, R.K.; Mehta, Y.; Trehan, N. Multivessel off-pump coronary artery bypass: Analysis of 4953 cases. Heart Surg. Forum 2003, 6, 153-159.

2. Shaefi, S.; Mittel, A.; Loberman, D.; Ramakrishna, H. Off-Pump Versus On-Pump Coronary Artery Bypass Grafting-A Systematic Review and Analysis of Clinical Outcomes. J. Cardiothorac. Vasc. Anesth. 2019, 33, 232-244. [CrossRef] [PubMed]

3. Cholesterol Treatment Trialists' (CTT) Collaboration; Baigent, C.; Blackwell, L.; Emberson, J.; Holland, L.E.; Reith, C.; Bhala, N.; Peto, R.; Barnes, E.H.; Keech, A. Efficacy and safety of more intensive lowering of LDL cholesterol: A meta-analysis of data from 170,000 participants in 26 randomised trials. Lancet 2010, 376, 1670-1681. [PubMed]

4. Baigent, C.; Keech, A.; Kearney, P.M.; Blackwell, L.; Buck, G.; Pollicino, C.; Kirby, A.; Sourjina, T.; Peto, R.; Collins, R.; et al. Efficacy and safety of cholesterol-lowering treatment: Prospective meta-analysis of data from 90,056 participants in 14 randomised trials of statins. Lancet 2005, 366, 1267-1278. [PubMed] 
5. Xing, Y.; Liu, J.; Hao, Y.; Liu, J.; Huo, Y.; Smith, S.C., Jr.; Ge, J.; Ma, C.; Han, Y.; Fonarow, G.C.; et al. Prehospital statin use and low-density lipoprotein cholesterol levels at admission in acute coronary syndrome patients with history of myocardial infarction or revascularization: Findings from the Improving Care for Cardiovascular Disease in China (CCC) project. Am. Heart J. 2019, 212, 120-128. [PubMed]

6. Komajda, M.; Cosentino, F.; Ferrari, R.; Kerneis, M.; Kosmachova, E.; Laroche, C.; Maggioni, A.P.; Rittger, H.; Steg, P.G.; Szwed, H.; et al. Profile and treatment of chronic coronary syndromes in European Society of Cardiology member countries: The ESC EORP CICD-LT registry. Eur. J. Prev. Cardiol. 2021, 28, 432-445. [CrossRef] [PubMed]

7. Schubert, J.; Lindahl, B.; Melhus, H.; Renlund, H.; Leosdottir, M.; Yari, A.; Ueda, P.; James, S.; Reading, S.R.; Dluzniewski, P.J.; et al. Low-density lipoprotein cholesterol reduction and statin intensity in myocardial infarction patients and major adverse outcomes: A Swedish nationwide cohort study. Eur. Heart J. 2021, 42, 243-252. [CrossRef]

8. Pourhosseini, H.; Lashkari, R.; Aminorroaya, A.; Soltani, D.; Jalali, A.; Tajdini, M. Effects of high dose atorvastatin before elective percutaneous coronary intervention on highly sensitive troponin $\mathrm{T}$ and one-year major cardiovascular events; a randomized clinical trial. Int. J. Cardiol. Heart Vasc. 2019, 22, 96-101. [CrossRef]

9. Sardella, G.; Conti, G.; Donahue, M.; Mancone, M.; Canali, E.; De Carlo, C.; Di Roma, A.; Calcagno, S.; Lucisano, L.; Fedele, F. Rosuvastatin pretreatment in patients undergoing elective PCI to reduce the incidence of myocardial periprocedural necrosis: The ROMA trial. Catheter. Cardiovasc. Interv. 2013, 81, E36-E43. [CrossRef]

10. Di Sciascio, G.; Patti, G.; Pasceri, V.; Gaspardone, A.; Colonna, G.; Montinaro, A. Efficacy of atorvastatin reload in patients on chronic statin therapy undergoing percutaneous coronary intervention: Results of the ARMYDA-RECAPTURE (Atorvastatin for Reduction of Myocardial Damage during Angioplasty) Randomized Trial. J. Am. Coll. Cardiol. 2009, 54, 558-565. [CrossRef]

11. Alam, S.R.; Stirrat, C.; Spath, N.; Zamvar, V.; Pessotto, R.; Dweck, M.R.; Moore, C.; Semple, S.; El-Medany, A.; Manoharan, D.; et al. Myocardial inflammation, injury and infarction during on-pump coronary artery bypass graft surgery. J. Cardiothorac. Surg. 2017, 12, 115. [CrossRef] [PubMed]

12. Park, J.; Lee, J.H.; Kim, K.A.; Lee, S.H.; Lee, Y.T.; Kim, W.S.; Min, J.J. Effects of Preoperative Statin on Acute Kidney Injury After Off-Pump Coronary Artery Bypass Grafting. J. Am. Heart Assoc. 2019, 8, e010892. [CrossRef] [PubMed]

13. Chen, S.; Wu, H.; Yang, T.; Li, B.; Hu, Y.; Sun, H. Does Early Graft Patency Benefit from Perioperative Statin Therapy? A Propensity Score-Matched Study of Patients Undergoing Off-Pump Coronary Artery Bypass Surgery. Cardiovasc. Ther. 2019, 2019, 1582183. [CrossRef]

14. Fernández-Macías, J.C.; Ochoa-Martínez, A.C.; Varela-Silva, J.A.; Pérez-Maldonado, I.N. Atherogenic Index of Plasma: Novel Predictive Biomarker for Cardiovascular Illnesses. Arch. Med. Res. 2019, 50, 285-294. [CrossRef]

15. Mach, F.; Baigent, C.; Catapano, A.L.; Koskinas, K.C.; Casula, M.; Badimon, L.; Chapman, M.J.; De Backer, G.G.; Delgado, V.; Ference, B.A.; et al. 2019 ESC/EAS Guidelines for the management of dyslipidaemias: Lipid modification to reduce cardiovascular risk. Eur. Heart J. 2020, 41, 111-188. [CrossRef]

16. Farkouh, M.E.; Godoy, L.C.; Brooks, M.M.; Mancini, G.B.J.; Vlachos, H.; Bittner, V.A.; Chaitman, B.R.; Siami, F.S.; Hartigan, P.M.; Frye, R.L.; et al. Influence of LDL-Cholesterol Lowering on Cardiovascular Outcomes in Patients With Diabetes Mellitus Undergoing Coronary Revascularization. J. Am. Coll. Cardiol. 2020, 76, 2197-2207. [CrossRef]

17. Navarese, E.P.; Robinson, J.G.; Kowalewski, M.; Kolodziejczak, M.; Andreotti, F.; Bliden, K.; Tantry, U.; Kubica, J.; Raggi, P.; Gurbel, P.A. Association between Baseline LDL-C Level and Total and Cardiovascular Mortality After LDL-C Lowering: A Systematic Review and Meta-analysis. JAMA 2018, 319, 1566-1579. [CrossRef]

18. Komukai, K.; Kubo, T.; Kitabata, H.; Matsuo, Y.; Ozaki, Y.; Takarada, S.; Okumoto, Y.; Shiono, Y.; Orii, M.; Shimamura, K.; et al. Effect of atorvastatin therapy on fibrous cap thickness in coronary atherosclerotic plaque as assessed by optical coherence tomography: The EASY-FIT study. J. Am. Coll. Cardiol. 2014, 64, 2207-2217. [CrossRef] [PubMed]

19. Nissen, S.E.; Nicholls, S.J.; Sipahi, I.; Libby, P.; Raichlen, J.S.; Ballantyne, C.M.; Davignon, J.; Erbel, R.; Fruchart, J.C.; Tardif, J.C.; et al. Effect of very high-intensity statin therapy on regression of coronary atherosclerosis: The ASTEROID trial. JAMA 2006, 295, 1556-1565. [CrossRef]

20. Geovanini, G.R.; Libby, P. Atherosclerosis and inflammation: Overview and updates. Clin. Sci. 2018, 132, 1243-1252. [CrossRef]

21. Diamantis, E.; Kyriakos, G.; Quiles-Sanchez, L.V.; Farmaki, P.; Troupis, T. The Anti-Inflammatory Effects of Statins on Coronary Artery Disease: An Updated Review of the Literature. Curr. Cardiol. Rev. 2017, 13, 209-216. [CrossRef]

22. Nissen, S.E.; Tuzcu, E.M.; Schoenhagen, P.; Brown, B.G.; Ganz, P.; Vogel, R.A.; Crowe, T.; Howard, G.; Cooper, C.J.; Brodie, B.; et al. Effect of intensive compared with moderate lipid-lowering therapy on progression of coronary atherosclerosis: A randomized controlled trial. JAMA 2004, 291, 1071-1080. [CrossRef] [PubMed]

23. Nicholls, S.J.; Ballantyne, C.M.; Barter, P.J.; Chapman, M.J.; Erbel, R.M.; Libby, P.; Raichlen, J.S.; Uno, K.; Borgman, M.; Wolski, K.; et al. Effect of two intensive statin regimens on progression of coronary disease. N. Engl. J. Med. 2011, 365, 2078-2087. [CrossRef] [PubMed]

24. Taqueti, V.R.; Ridker, P.M. Lipid-Lowering and Anti-Inflammatory Benefits of Statin Therapy: More Than Meets the Plaque. Circ. Cardiovasc. Imaging 2017, 10, e006676. [CrossRef] [PubMed]

25. Bhatt, D.L.; Miller, M.; Brinton, E.A.; Jacobson, T.A.; Steg, P.G.; Ketchum, S.B.; Doyle RTJr Juliano, R.A.; Jiao, L.; Granowitz, C.; Tardif, J.C.; et al. REDUCE-IT USA: Results From the 3146 Patients Randomized in the United States. Circulation 2020, 141, 367-375. [CrossRef] 
26. Pan, Y.; Tan, Y.; Li, B.; Li, X. Efficacy of high dose rosuvastatin preloading in patients undergoing percutaneous coronary intervention: A meta-analysis of fourteen randomized controlled trials. Lipids Health Dis. 2015, 14, 97-109. [CrossRef] [PubMed]

27. Marenzi, G.; Cosentino, N.; Cortinovis, S.; Milazzo, V.; Rubino, M.; Cabiati, A.; De Metrio, M.; Moltrasio, M.; Lauri, G.; Campodonico, J.; et al. Myocardial Infarct Size in Patients on Long-Term Statin Therapy Undergoing Primary Percutaneous Coronary Intervention for ST-Elevation Myocardial Infarction. Am. J. Cardiol. 2015, 116, 1791-1797. [CrossRef]

28. Auguadro, C.; Manfredi, M.; Scalise, F.; Mortara, A.; Specchia, G. Protective role of chronic statin therapy in reducing myocardial damage during percutaneous coronary intervention. J. Cardiovasc. Med. 2006, 7, 416-421. [CrossRef] [PubMed]

29. Lippi, G.; Mattiuzzi, C.; Sanchis-Gomar, F. Routine cardiac troponin assessment after percutaneous coronary intervention: Useful or hype? J. Cardiovasc. Med. 2019, 20, 495-499. [CrossRef]

30. Ndrepepa, G.; Colleran, R.; Braun, S.; Cassese, S.; Hieber, J.; Fusaro, M.; Kufner, S.; Ott, I.; Byrne, R.A.; Husser, O.; et al. High-Sensitivity Troponin T and Mortality After Elective Percutaneous Coronary Intervention. J. Am. Coll. Cardiol. 2016, 68, 2259-2268. [CrossRef]

31. Nienhuis, M.B.; Ottervanger, J.P.; Bilo, H.J.; Dikkeschei, B.D.; Zijlstra, F. Prognostic value of troponin after elective percutaneous coronary intervention: A meta-analysis. Catheter. Cardiovasc. Interv. 2008, 71, 318-324. [CrossRef] [PubMed]

32. Wang, T.K.; Stewart, R.A.; Ramanathan, T.; Kang, N.; Gamble, G.; White, H.D. Diagnosis of MI after CABG with high-sensitivity troponin T and new ECG or echocardiogram changes: Relationship with mortality and validation of the universal definition of MI. Eur. Heart J. Acute Cardiovasc. Care 2013, 2, 323-333. [CrossRef]

33. Muehlschlegel, J.D.; Perry, T.E.; Liu, K.Y.; Nascimben, L.; Fox, A.A.; Collard, C.D.; Avery, E.G.; Aranki, S.F.; D’Ambra, M.N.; Shernan, S.K.; et al. Troponin is superior to electrocardiogram and creatinine kinase MB for predicting clinically significant myocardial injury after coronary artery bypass grafting. Eur. Heart J. 2009, 30, 1574-1583. [CrossRef] [PubMed]

34. Machado, M.N.; Rodrigues, F.B.; Grigolo, I.H.; Sabbag, A.T.R.; Silva, O.L., Jr.; Maia, L.N.; Nakazone, M.A. Early Prognostic Value of High-Sensitivity Troponin T after Coronary Artery Bypass Grafting. Thorac. Cardiovasc. Surg. 2019, 67, 467-474. [CrossRef] [PubMed]

35. Lurati Buse, G.A.; Koller, M.T.; Grapow, M.; Bolliger, D.; Seeberger, M.; Filipovic, M. The prognostic value of troponin release after adult cardiac surgery-A meta-analysis. Eur. J. Cardiothorac. Surg. 2010, 37, 399-406. [CrossRef] 